\title{
Development of Care Learning E-Module for Discovery Learning Based on Students of Makeup Studies Education Program, Medan State University
}

\author{
Dwiyati Wuri \\ Program of Postgraduate, \\ Universitas Negeri Medan \\ Medan, Indonesia \\ dwii.wuridwiyatispd@gmail.com
}

\begin{abstract}
The study is intended to : (1) determine the feasibility of e- module learning care agency based discovery learning, and (2) determine the effectiveness of the e- module learning care agency based discovery learning . Type of research this is the research development using the product Borg and Gall were combined with the model of development of learning Dick and Carey. This model includes six stages namely : literature study, planning and design development, product development , expert validation , trials, revisions, and final products . Subject test try consists of a two- person expert material , two- person expert design of learning, two expert video media learning, three the students to test individual, Nine students for the test group of small , and four thirty the students to test the field. The result of the filing of hypotheses prove that : (1) the media emodules of learning worthy of use in learning care agency on the program of study education tat a dressing university land terrain , (2) there is a difference that is significant between the results of learning of students who be taught to use the e- module learning care agency with the result of learning of students who be taught to use the media to learn the book text . This is indicated by the results of data processing $t$ arithmetic $=3.285$ at a significance level $\alpha=0.05$ with dk 40 obtained $t$ table $=1.67$, so $t$ arithmetic $>$ $t$ table , the effectiveness of using e- module body care learning = $80.46 \%$. Results of study groups of students who be taught without the use of e- module learning care agency by $71.72 \%$. From the data have proved that the use of e- module learning care agencies more effective in improving the competence and knowledge of students on study treatment weight of at without using the medium of e- modules of learning care .
\end{abstract}

Keywords- Discovery Learning, Development of E-Module Learning Care Agency

\section{INTRODUCTION}

Information and Communication Technology (ICT) is currently highly developed in society. Generally Information Technology is a technology that is used to manage data, including in it: processing, obtaining, compiling, storing, manipulating data in a variety of ways and procedures to produce quality information and high-value use. The development of ICT continues to increase along with the increasing human needs, especially in the field of Education [1]. At present the trend of the use of e-electronic, which means a lot of emerging, such as e-education, e-learning, and so on, including the use of e-modules. At present information technology seems to have become a teacher, book and learning system that is conventional. By because it is , with increasingly growing progress in the field of science knowledge and technology Institutions especially college high that competence in the field of vocational already preparing the source power of man that is the students who are competent in the field of expertise of each one of them in the field of expertise order beauty or cosmetology.

University of Medan is one of the Institutions of Education State which has a program expertise competence vocational in the field of governance of beauty. Program Study of Educational Makeup Department of Education Welfare and Family Faculty of Engineering is a program of study that opened since the teachings of 2007/2008 was one of the efforts to meet the needs in the community will be the teachers professional and skilled in the fields of cosmetology in the future will come. Improved quality of teaching in universities high, especially in institutes of Education personnel education is and must continue to be improved. Based on the results of interviews with faculty pengampu eyes of college nursing agency implemented on the date of 17 January 2019 can be concluded that during these lectures carried out only with the methods of lecture and demonstration. Practices are simulated first advance by the lecturers can spend time almost 2 credits and subsequent student practice it together. While the result of learning of students associated with the eyes of college nursing agency, the data obtained from the results of learning of students in the eyes of college nursing agency in the teachings of $2016 / 2017$ is said to be good. This can be seen from there are $22.85 \%$ who get very good grades and $77.15 \%$ who get good grades. Although the result of learning of students in the eyes of college nursing agency pertained to say good, but still 
need to be improved so that the results of study a student may be retained or more improved again so that the purpose of the process of learning can be achieved in accordance with the expected .

The role of lecturers as educators is needed to motivate student enthusiasm for learning. For the lecturer is seen as a person who knows a lot of things about the conditions of learning and also the problems of learning that faced by students. Lecturers are creative are always innovating and looking for ways how to make the process of learning to teach achieve the result of learning in accordance with the objectives that are planned. Based on the results of observations are made on the date of 25 January 2019 with the lecturer pengampu eyes of college nursing agency can be concluded that the reactions of students during the process of learning care agency is a student looks very enthusiastic both from the terms of the deepening of the material as well as the current treatment practice. Although there are some students who look less active in the learning in the classroom, but the lecturer pengampu eyes of college trying to provide approach both in apperception, appreciation and motivates him to improve his spirits in peroses activities of learning care agency [2]

The use of media and learning resources is part of the components that influence learning . Materials teaching need to be adapted to the conditions of the students and strategies of learning that is used lecturer. Utilization and empowerment of modules to support learning is an advancement, not only to improve the effectiveness and quality of learning, but what is more important is to improve the mastery of the material both faculty and students [3].

To increase the activity of the participant students in the class in the process of learning, things that can be addressed by applying the model of learning, the success of a participant students in the process of learning is not only determined by the force instructor that good or curriculum that is steady, but is also determined by the method of learning the use of teachers. Models or methods of teaching that require activeness of students in accordance with the progress of students. Activeness learning students can be seen from the activities of learning students, among others: visual activities, oral activities, listening activities, writing activities, drawing activities, the motor activities, mental activities, and emotional activities [4].

To provide the material teaching in accordance with the development of the times, it can be assisted by the provision of a module teaching, a module teaching would be meaningless, if the student can with easy to use. The teaching modules that are currently in accordance with technological developments are electronic based. Teaching module electronics that when it popular is the Modular Object-Oriented Dynamic Learning Environment (Moodle), ie the module electronics are based on the web. Moodle is a name for a Program is an application that can transform a medium of learning into the form of a web [5$10]$.

In connection with this the author would like to develop an e- module that is by applying one of the models of learning in e- modules , namely discovery learning. Research that will writer to develop these, entitled " Development of E-Module
Learning Care Agency -Based Discovery Learning On Student Program Study of Educational Makeup Universitas Negeri Medan".

\section{RESEARCH METHOD}

This research was conducted to produce an electronic module for learning body care . Type of research have included research and development (Research and Development). This research was conducted at Medan State University , Faculty of Engineering, Department of Family Welfare Education , Makeup Study Program .

Subjects in the study this is a matter of learning the eyes of college nursing agency. While the object of the research it is the students Program Study of Educational Makeup who were studying the matter of learning the eyes of college nursing agency.

To find out the result of learning of students with the application of e- module learning care agency based discovery learning, the researchers did the collection of data research by using the instrument of research that tests and pieces of observation ( observation ). Observations were carried out in the form of observation of the entire activities of the process of learning to teach and aims to determine the changes that occur when do the action. Before sheet observation is used as an instrument of research, especially first sheet of observation is in validated by a team of expert validation .

To test the research instrument test, use a validity test, reliability test, test the level of difficulty test, and different power test.Analysis of the data in the study is using stage test for normality, test of homogeneity, and t test.

\section{RESULTS AND DISCUSSION}

Results of the study showed ; (1) the learning material expert test is in very good qualification $(93.75 \%)$, (2) the learning design expert test is in good qualification $(80.08 \%)$, (3) the learning video media expert test is in a very good qualification $(89,99 \%)$

The result of the filing of hypotheses prove that : (1) the media e- modules of learning worthy of use in learning care agency on the program of study education tat a dressing university land terrain , (2) there is a difference that is significant between the results of learning of students who be taught to use the e- module learning care agency with the result of learning of students who be taught to use the media to learn the book text. This is indicated by the results of data processing $\mathrm{t}$ arithmetic $=3.285$ at a significance level $\alpha=0.05$ with dk 40 obtained t table $=1.67$, so $t$ arithmetic $>t$ table, the effectiveness of using e- module body care learning $=80.46 \%$. Results of study groups of students who be taught without the use of e- module learning care agency by $71.72 \%$. From the data have proved that the use of e- module learning care agencies more effective in improving the competence and knowledge of students on study treatment weight of at without using the medium of e- modules of learning care . 


\section{CONCLUSION}

Based on the formula, objectives, results and discussion of research development of the e- module learning care agency whose stated earlier, it can be summed up as follows :

After passing through several phases of test try , either test try of expert material, test try expert design learning, and test try from expert video and desian graphics and test try to students, the product e- module learning dressing characters have the result already decent into the product end of the can be disseminated and implemented to the user . It is clarified with the acquisition of the average ratings almost all stages, ie in a test try expert materials on the table a scale of five, niali that included the category " very good ", the test try expert design learning in the tables scale of five, the value of the included category of " Good ", In the trials of the experts in the five scale table, the value is included in the category of " very good ", in the one-on-one trial in the five scale table , the value is included in the " very good " category, in the small group trials in the five scale table, the value is included in the category of " very good ", in the field trials in the five scale table, the value is included in the " very good " category .

To see the effectiveness of the product, an analysis of student learning outcomes was carried out. Based on the analysis of student participants test try to group a large result of use of e- module learning care agency on the test results of learning of students showed that the result of learning of students who be taught to use the e- module learning .

\section{REFERENCES}

[1] Mursid , R. (2017). Technology of Information and Communication (ICT) in Education -Based Higher Order Thinking Skills (HOTS). North Sumatra: CV. Echo Ihsani

[2] Putra, KWB, Wirawan, IM A \& Pradnyana , GA (2017). Development of E-Module -Based Model of Learning Discovery Learning On the Subject " Systems Computer " For Students Class X Multimedia Smk Negeri 3 Singaraja . Journal of Technology and Vocational Education Vol. 14, No.1,(https://www.researchgate.net/publication/315302769, accessed 25 March 2017)

[3] Suarsana, IM and Mahayukti , GA (2013). " Development of E-Module Oriented Solving Problems to Improve Skills Thinking Critical Student ". Indonesian Education Journal . Vol. 2 (2):266.(https://ejournal.undiksha.ac.id/index.php/JPI/article/view/2171)

[4] Sardirman . (2007). Interaction and Teaching and Learning Motivation . Jakarta: PT Raja Grafindo Persada .

[5] Priyanthi , KA (2017). " Development of E-Modules Aided by Simulation Oriented Problem Solving in Data Communication Subjects ( Case Study : Students of Class XI TKJ SMK N 3 Singaraja )". KARMAPATI Journal Volume 6 no.1,(https://ejournal.undiksha.ac.id/index.php/KP/article/view/9267, accessed in 2017)

[6] Seel , NM (2012). Encyclopedia of Science of learning. New York: Springer.

[7] Sudjana . (2005). Statistics method ( 6th edition). Bandung: Tarsito

[8] Solihatin , Etin and Raharjo . (2008). Cooperative Learning: Analysis of Social Studies Learning . Jakarta: PT. Earth Literacy .

[9] Sudijono , Anas. (2011). Introduction to Educational Evaluation Jakarta: PT. RajaGrafindo Persada .

[10] Suprijono , Agus . (2010). Cooperative Learning: Theory and Application of PAIKEM. Yogyakarta: Student Library . 